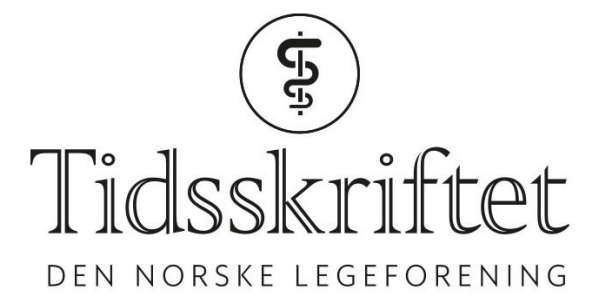

\title{
Inhalering av mRNA som medisin
}

FRA ANDRE TIDSSKRIFTER

RUTH HALSNE

Tidsskriftet

Inhalasjon av stabile nanopartikler med innkapslet mRNA som koder for luciferase, ga økt luciferasemengde i lungevev hos mus. 


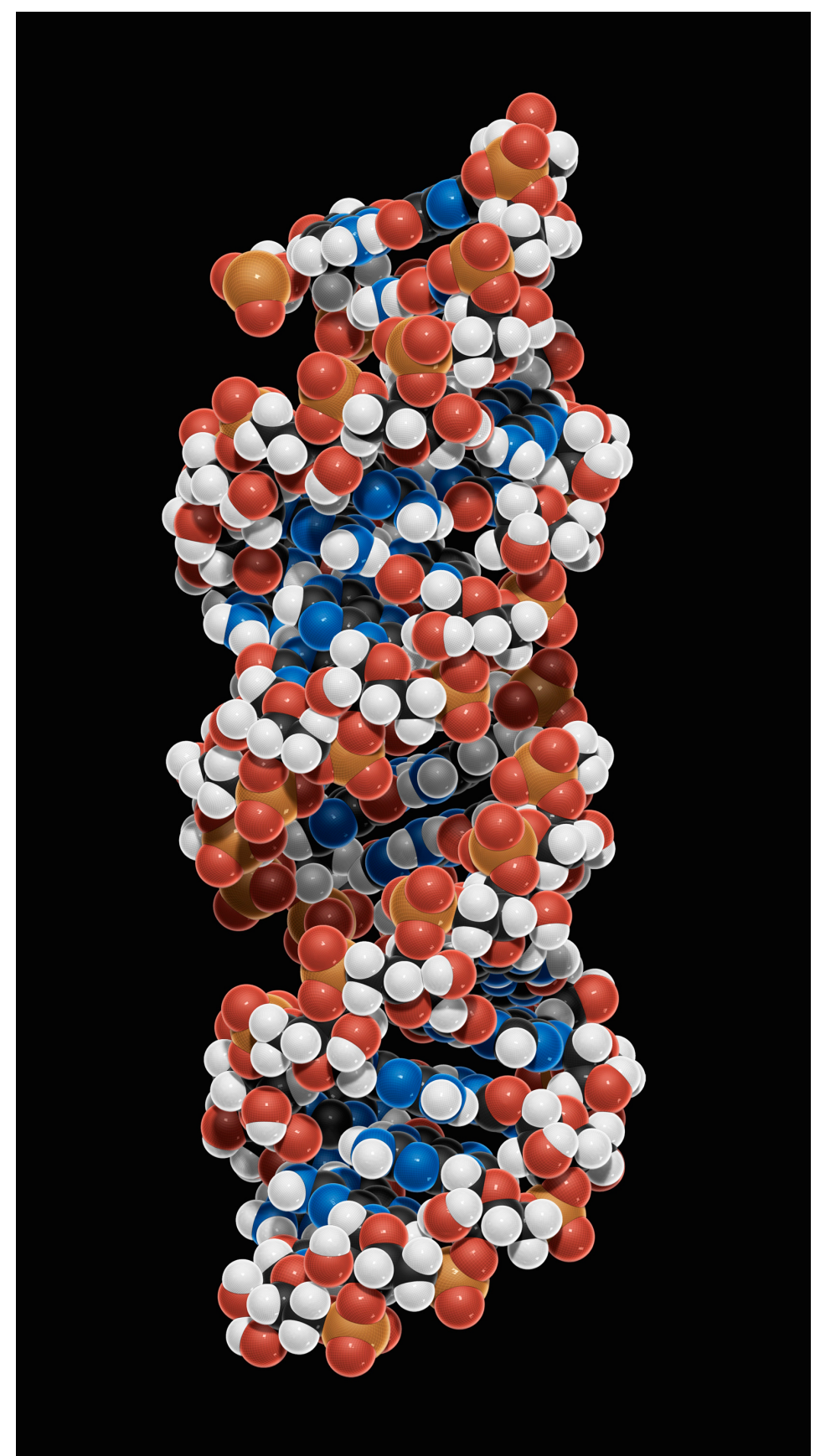

mRNA. Illustrasjon: Science Photo Library

Lokalbehandling av sykdommer i lungene er ofte å foretrekke fremfor systemisk behandling. I en ny studie ble nanopartikler av polymerer koblet til mRNA som koder for luciferase, et enzym som styrer danningen av lys i celler og vev (bioluminiscens), testet i epiteliale lungeceller (1). Formelen ble gitt til mus ved hjelp av inhalasjonskammer, og etter 24 timer ble flere organer tatt ut. Distribusjonen av mRNA ble så undersøkt ved å måle bioluminiscens og proteinmengde i lungevev. Luciferase var jevnt uttrykt i lungevev, og rundt en firedel av epitelcellene inneholdt luciferace etter kun én dose.

- I denne studien har forskerne klart å utvikle stabile nanopartikler med innkapslet mRNA, sier Marianne Hiorth, professor i galenisk farmasi ved Farmasøytisk institutt, Universitetet i Oslo. I riktig mengdeforhold dannes nanopartiklene spontant fordi polymeren har positiv ladning, mens mRNA har negativ ladning.

- Utfordringen videre er å utvikle nye nanoadministrasjonssystemer til lungene med en tilfredsstillende stabilitet av partiklene, noe som vil påvirke avsetning i lungene. I denne studien ble stabilitetsproblemene løst ved å frysetørke nanopartiklene. Sluttstørrelsen på partiklene ble kontrollert ved hjelp av et forstøverapparat og ga en gunstig partikkelstørrelse for avsetning på riktig sted. 
- Det vil være interessant å se om dette administrasjonssystemet kan benyttes til å kapsle inn mRNA som koder for proteiner som kan være effektive ved behandling av sykdom i lungene, sier Hiorth.

LITTERATUR:

1. Patel AK, Kaczmarek JC, Bose S et al. Inhaled nanoformulated mRNA polyplexes for protein production in lung epithelium. Adv Mater 2019; 1805116: e1805116. [PubMed][CrossRef]

Publisert: 28. februar 2019. Tidsskr Nor Legeforen. DOI: 10.4045/tidsskr.19.0118

(C) Tidsskrift for Den norske legeforening 2020. Lastet ned fra tidsskriftet.no 